\title{
Natural dye extracted from Pandannus amaryllifolius leaves as sensitizer in fabrication of dye-sensitized solar cells
}

\author{
Mahmoud A. M. Al-Alwani ${ }^{1,4}$, Abu Bakar Mohamad ${ }^{1,3}$, Abd Amir H. Kadhum ${ }^{1}$, Norasikin A. Ludin ${ }^{2}$ \\ N. E. Safie ${ }^{2}$, M. Z. Razali ${ }^{2}$, M. Ismail ${ }^{2}$,Kamaruzzaman Sopian ${ }^{2}$ \\ ${ }^{1}$ Department of Chemical and Process Engineering, Faculty of Engineering and Built Environment, \\ Universiti Kebangsaan Malaysia, 43600 Bangi, Selangor, Malaysia \\ ${ }^{2}$ Solar Energy Research Institute (SERI), Universiti Kebangsaan Malaysia, Bangi, 43600 Selangor, \\ Malaysia \\ ${ }^{3}$ Fuel Cell Institute, Universiti Kebangsaan Malaysia, Bangi, 43600 Selangor, Malaysia \\ ${ }^{4}$ Department of Biology, College of Education for Pure Sciences/Ibn Al-Haitham, University of \\ Baghdad, Baghdad, Iraq \\ *Email address: mamash73@yahoo.com
}

doi: $10.20964 / 2017.01 .56$

Received: 25 August 2016 / Accepted: 16 November 2016 / Published: 12 December 2016

\begin{abstract}
A dye-sensitized solar cell (DSSC) was fabricated with natural chlorophyll dye extracted from pandan (Pandannus amaryllifolius) leaves as natural sensitizer. Chlorophyll dye was extracted from pandan leaves using different organic solvents, namely, ethanol, acetonitrile, chloroform, ethyl ether, and methanol, to determine the effects of solvent type on the extraction. The optical and structural properties of the natural extract were also analyzed. UV-Vis spectrophotometer and Fourier transmission infrared studies (FTIR) indicated the presence of chlorophyll in pandan leaves. The absorption spectrum of the dye extract was compared with that of the dye adsorbed onto the $\mathrm{TiO}_{2}$ surface. The dye structure was then confirmed through X-ray diffraction analysis (XRD). The effectiveness of electron transfer was found to be related to the interaction between the chlorophyll dye and the $\mathrm{TiO}_{2}$ film surface. The morphological properties and composition of dyes were analyzed through scanning electron microscope (SEM) and EDX studies. The photovoltaic response of DSSC was investigated by recording $I-V$ characteristics under illumination. DSSC sensitized with the pandan extract yielded the following parameters: $I s c=0.4 \mathrm{~mA}, V o c=0.559 \mathrm{~V}, P \max =0.1 \mathrm{~W}, F F=60.51 \%$ and $\eta=0.1 \%$.
\end{abstract}

Keywords: DSSC, Pandannus amaryllifolius, chlorophyll, sensitizers, solvents 
(C) 2017 The Authors. Published by ESG (www.electrochemsci.org). This article is an open access article distributed under the terms and conditions of the Creative Commons Attribution license (http://creativecommons.org/licenses/by/4.0/). 